\title{
Effects of supplementation of betaine hydrochloride on physiological performances of broilers exposed to thermal stress
}

\author{
Abhay K Singh' \\ Tapan K Ghosh' \\ David C Creswell ${ }^{2}$ \\ Sudipto Haldar' \\ 'Department of Animal Nutrition, \\ Faculty of Veterinary and Animal \\ Sciences, West Bengal University of \\ Animal and Fishery Sciences, Kolkata, \\ India; ${ }^{2}$ Creswell Nutrition, Sydney, \\ Australia
}

This article was published in the following Dove Press journal:

Open Access Animal Physiology

6 July 2015

Number of times this article has been viewed
Background: Betaine has the potential to spare methionine and choline as methyl-group donors, and is thought to improve broiler performance under conditions of stress. An experiment was conducted to ascertain the effects of supplemental betaine on performances and physiological responses of broilers exposed continuously to thermal stress.

Materials and methods: Male broilers ( $\mathrm{n}=128$, divided into four groups, with eight replicate cages in a group) received diets containing suboptimal levels of methionine and metabolizable energy and supplemented with $1.3 \mathrm{~g} / \mathrm{kg}$ and $2 \mathrm{~g} / \mathrm{kg}$ betaine hydrochloride from day 1 to 38 . The positive control (PC) did not contain supplemental betaine, and the negative control (NC), to which betaine was added, was deficient in methionine and energy and devoid of added choline. The experiment included assessment of growth, feed-conversion ratio, rectal temperature and respiration rates, and assay of blood hormones and metabolites.

Results: Betaine at both the levels of inclusion improved live weight and feed intake over the PC and the NC groups. Rectal temperature and respiration rates were also lower in the betainesupplemented groups, indicating a sequestering effect of betaine on metabolic rates of thermally stressed broilers. Carcass yield was unaffected. Betaine-supplemented groups had better thyroid activity than the NC and PC groups of birds.

Conclusion: Based on this study, it was inferred that in tropical countries betaine may be effectively used to ameliorate the negative impact of high ambient temperature in broiler chickens. The findings also suggest that at an appropriate dose, betaine may spare some quantity of DLmethionine and dietary energy to support the growth process of heat-stressed broilers. However, further studies are warranted to assign a definite methionine and energy matrix to supplemental betaine that can be used in broiler diets without inviting any risk of drop in production.

Keywords: betaine, broiler chickens, heat stress, performance, physiological responses

\section{Introduction}

Combating heat stress remains a challenge for the broiler industry in the tropics, and efforts are under way to develop dietary measures that can ameliorate heat stress to achieve optimum performance. Exposure to high ambient temperature causes serious physiological dysfunctions and triggers secretion of corticosteroids, which being catabolic in nature severely depress animal performance. ${ }^{1,2}$ The term "stress" is commonly used to describe the detrimental effects of a variety of situations on the health and performance of poultry, and may be defined as the set of responses to external demands that call upon the flocks to adapt to a new and an abnormal situation. ${ }^{3}$ This adaptation process releases hormones and redistributes nutrient reserves at the cost of performance..$^{4-6}$ The thermoneutral zone for poultry is $18^{\circ} \mathrm{C}-24^{\circ} \mathrm{C}$ in the tropics
Correspondence: Sudipto Haldar Department of Animal Nutrition, Faculty of Veterinary and Animal Science, West Bengal University of Animal and Fishery Sciences, 37 Kshudiram Bose Sarani, Kolkata, West Bengal 700037, India Tel +9l 983647779 |

Email sudipto.haldar@gmail.com submit your manuscript | www.dovepress.com

Dovepress

http://dx.doi.org// 0.2147/OAAP.S83190
Open Access Animal Physiology 2015:7 I II-120 
and $12^{\circ} \mathrm{C}-26^{\circ} \mathrm{C}$ in the temperate zones, but this often gets exceeded in the tropics, resulting in heat stress. ${ }^{7,8}$ By elevating circulatory corticosteroids and decreasing thyroid activity, heat stress impairs broiler performance, especially in adult birds, because the ability to dissipate heat decreases with age. ${ }^{9}{ }^{10}$ Drastic decline in feed intake occurs in heat-stressed birds as a physiological response to minimize intrinsic heat production and to maintain the thermal homeostasis, thus bringing down feed efficiency, live weight gain, and survival rates. ${ }^{11-14}$ Lower breast-meat yield and higher carcass-fat deposition are the other deleterious effects of heat stress that lower the economic value of broiler carcasses. ${ }^{10,11,15}$

Betaine, the trimethyl derivative of the amino acid glycine, is a naturally occurring compound distributed widely in many plants and animal tissues. ${ }^{16}$ Betaine has multiple functions that include donation of its labile methyl group, which is used in transmethylation reactions for synthesis of carnitine and creatine. ${ }^{17,18}$ Dietary supplementation of betaine presumably reduces the requirement for other methyl-group donors, such as methionine and choline. ${ }^{19}$ As a feed additive, betaine is most commonly added to animal diets as anhydrous betaine, betaine monohydrate, and betaine hydrochloride. ${ }^{17,18}$ Betaine hydrochloride is a chemically synthesized product containing trimethylamine (TMA). It has been a matter of apprehension that the widely varying TMA content in betaine $\mathrm{HCl}$ may pose some risk for chickens being fed on diets containing betaine $\mathrm{HCl}$. However, the European Food Safety Authority indicated that for meat- and egg-purpose chickens, the safe level of dietary TMA and its salt is as high as $2 \mathrm{mg} / \mathrm{kg}$ body weight (15 mg/kg feed) and $3 \mathrm{mg} / \mathrm{kg}$ body weight ( $24 \mathrm{mg} / \mathrm{kg}$ feed), respectively, which provides enough safety margin for inclusion of betaine $\mathrm{HCl}$ in poultry diets. ${ }^{20}$ Within the body, betaine is synthesized from choline. ${ }^{21,22}$ Being a methylgroup donor, betaine is thought to spare methionine from this function, thus allowing methionine to be utilized more for growth and muscle development. ${ }^{23}$ Choline presumably alleviates heat stress in broilers due to its ability to be oxidized readily to betaine, which is then used as a methyl-group donor to synthesize methionine. Therefore, both betaine and choline are considered to be potential methyl-group donors, and are hypothesized to spare methionine, at least partially, particularly in conditions where dietary methionine is limited to some extent. ${ }^{24}$

The present experiment was conducted with broilers exposed continuously to high temperature and humidity. It was hypothesized that being a methyl donor, betaine should compensate for methionine functions as a methyl-group donor in situations where methionine is deficient in diets. ${ }^{25}$
It was also hypothesized that betaine may be capable of sparing choline altogether, and may conserve the energy consumed in the process of the conversion of choline into betaine. The experimental diets did not contain any added choline, and were suboptimal in methionine. Although the available literature suggests that methionine may be spared by betaine, the exact amount of methionine that can be replaced with betaine is not available. Also, to our knowledge, there are no data available on the energy-sparing effect of betaine. The present study attempted to derive a methionine and energy matrix of betaine hydrochloride in heat-stressed broilers. The objective was to gauge the performance and physiological responses of thermally stressed broilers fed diets containing suboptimal levels of methionine and metabolizable energy and supplemented with different levels of betaine hydrochloride, and to corroborate these responses with some metabolic indices in blood.

\section{Materials and methods Bird husbandry and experimental diets}

The trial was conducted according to institutional ethical norms. One-day-old male Cobb 400 chicks $(n=128)$ were used in a 38-day feeding trial. There were four dietary treatments, and each treatment had eight replicate cages with four birds in each cage. The cages were kept in an experimental room that was artificially illuminated and had provision for ventilation and heating. Each cage measured $0.3 \times 0.3 \mathrm{~m}$, with feeders and drinkers fitted outside. Immediately after receipt, the chicks were weighed individually and put inside the cage, where they could get access to the designated treatment diets instantly. Assignment of chicks into the cages was done following a completely randomized design, so that cage-related variation in performance could be minimized as far as possible. Dark periods of 2 hours and 4 hours per day were maintained during days 1-16 and 17-38, respectively. The birds were vaccinated against the Newcastle disease (live attenuated strain) on days 7 and 20 and the infectious bursal disease on day 14 . The temperature of the experimental room varied between $28^{\circ} \mathrm{C}$ (night) to $35^{\circ} \mathrm{C}$ (day). Electrical heaters were used intermittently to increase and maintain the constancy in temperature. Maximum and minimum temperatures and relative humidity $(\mathrm{RH})$ in the experimental room were measured using a thermohygrometer at $7 \mathrm{am}, 2 \mathrm{pm}$, and 7 pm every day.

As outlined in the objectives, the experimental diets were formulated with suboptimal levels of methionine and metabolizable energy. Based on the available literature, it was presumed that betaine would be capable of sparing 
$800 \mathrm{mg}$ of digestible methionine per kilogram of the diet. An energy matrix of $200 \mathrm{KJ} / \mathrm{kg}$ was assigned to betaine as well. Therefore, the experimental diets were: 1) a positive control (PC) without any supplemental betaine and formulated according to industry standards; 2) a negative control (NC), which was devoid of any added choline chloride, deficient in metabolizable energy by $200 \mathrm{KJ} / \mathrm{kg}$, and the quantity of added DL-methionine decreased by $33 \%$ in both the starter and grower diets; 3) Bet 1.3, which was similar to $\mathrm{NC}$ and was supplemented with $1.3 \mathrm{~g}$ betaine $\mathrm{HCl} / \mathrm{kg}$; and 4) Bet 2.0, which was similar to the $\mathrm{NC}$ diet and was supplemented with $2.0 \mathrm{~g}$ betaine $\mathrm{HCl} / \mathrm{kg}$. Feed and water was offered ad libitum. The starter (days 1-16) and grower mash (days 17-38) (Table 1) were analyzed for dry matter (heating at $105^{\circ} \mathrm{C}$ for $16-18$ hours), ash (combustion at $550^{\circ} \mathrm{C}$ to constant weight), crude protein as nitrogen $\times 6.25$ (by the semimicro-Kjeldahl method; Kjeltec Auto System; Tecator $\mathrm{AB}$, Höganäs, Sweden), and lipid (diethyl ether extraction in a Fosstec analyzer [Tecator] after $\mathrm{HCl}$ hydrolysis).

\section{Measurements}

Live weight gain, feed intake, and feed-conversion ratio (FCR; intake:live weight gain) were calculated cage-wise for each period (days 1-16, 17-38) and for the overall

Table I Ingredient composition of the experimental diets

\begin{tabular}{|c|c|c|c|c|c|c|c|c|}
\hline \multirow[t]{2}{*}{ Ingredients g/kg } & \multicolumn{4}{|c|}{ Starter diets (days I-I6) } & \multicolumn{4}{|c|}{ Grower diet (days I7-38) } \\
\hline & PC & NC & Bet I.3 & Bet 2.0 & PC & NC & Bet I.3 & Bet 2.0 \\
\hline \multicolumn{9}{|l|}{ Ingredient composition } \\
\hline Yellow corn & 514.4 & 526.3 & 525 & 524.3 & 633.9 & 643.9 & 642.6 & 641.9 \\
\hline Soybean meal & 409 & 407 & 407 & 407 & 307 & 305 & 305 & 305 \\
\hline Soybean oil & 38 & 29 & 29 & 29 & 25 & 17 & 17 & 17 \\
\hline Limestone powder & 6.4 & 6.4 & 6.4 & 6.4 & 5.9 & 5.9 & 5.9 & 5.9 \\
\hline Dicalcium phosphate & 19.8 & 19.8 & 19.8 & 19.8 & 16.8 & 16.8 & 16.8 & 16.8 \\
\hline Salt & 2.7 & 2.7 & 2.7 & 2.7 & 2.1 & 2.1 & 2.1 & 2.1 \\
\hline Sodium bicarbonate & 2 & 2 & 2 & 2 & 2 & 2 & 2 & 2 \\
\hline L-lysine hydrochloride & 1.2 & 1.3 & 1.3 & 1.3 & $\mathrm{I} .5$ & 1.5 & $\mathrm{I} .5$ & 1.5 \\
\hline DL-methionine & 2.7 & 1.8 & 1.8 & 1.8 & 2.3 & 1.5 & 1.5 & 1.5 \\
\hline L-threonine & 0.3 & 0.3 & 0.3 & 0.3 & 0.5 & 0.5 & 0.5 & 0.5 \\
\hline Choline chloride $60 \%$ & 1.0 & - & - & - & 0.5 & - & - & - \\
\hline Vitamin-mineral premix ${ }^{a}$ & 2.0 & 2.0 & 2.0 & 2 & 2 & 2 & 2 & 2 \\
\hline Salinomycin $12 \%^{\mathrm{b}}$ & 0.5 & 0.5 & 0.5 & 0.5 & 0.5 & 0.5 & 0.5 & 0.5 \\
\hline Betaine hydrochloride & - & - & 1.3 & 2.0 & - & - & 1.3 & 2 \\
\hline Deoiled rice branc & - & 0.9 & 0.9 & 0.9 & - & 1.3 & 1.3 & $\mathrm{I} .3$ \\
\hline Metabolizable energy, $\mathrm{MJ} / \mathrm{kg}^{\mathrm{d}}$ & 12.34 & 12.14 & 12.14 & 12.14 & 12.52 & 12.32 & 12.32 & 12.32 \\
\hline Crude protein ${ }^{\mathrm{e}}$ & 223.7 & 222.6 & 223.1 & 222.9 & 188.6 & 187.5 & 187.8 & I88. I \\
\hline Calcium $^{\mathrm{e}}$ & 8.23 & 8.15 & 8.18 & 8.21 & 7.21 & 7.33 & 7.15 & 7.09 \\
\hline Total phosphorus ${ }^{\mathrm{e}}$ & 7.75 & 7.67 & 7.78 & 7.82 & 6.79 & 6.81 & 6.82 & 6.77 \\
\hline Available phosphorus $^{d}$ & 4.1 & 4.1 & 4.1 & 4.1 & 0.35 & 0.35 & 0.35 & 0.35 \\
\hline \multicolumn{9}{|l|}{ Digestible amino acids ${ }^{d}$} \\
\hline Lysine & 12.2 & 12.3 & 12.3 & 12.3 & 10.3 & 10.2 & 10.2 & 10.2 \\
\hline Methionine & 5.6 & 4.8 & 4.8 & 4.8 & 4.9 & 4.1 & 4.1 & 4.1 \\
\hline Methionine + cysteine & 8.6 & 7.7 & 7.7 & 7.7 & 7.5 & 6.7 & 6.7 & 6.7 \\
\hline Threonine & 7.5 & 7.5 & 7.5 & 7.5 & 6.6 & 6.6 & 6.6 & 6.6 \\
\hline Tryptophan & 2.1 & 2.2 & 2.2 & 2.2 & 1.8 & 1.8 & 1.8 & 1.8 \\
\hline Arginine & 14.6 & 14.7 & 14.7 & 14.7 & 11.9 & 11.9 & 11.9 & 11.9 \\
\hline Valine & 9.5 & 9.5 & 9.5 & 9.5 & 8.1 & 8.1 & 8.1 & 8.1 \\
\hline Isoleucine & 8.6 & 8.7 & 8.7 & 8.7 & 7.1 & 7.1 & 7.1 & 7.1 \\
\hline Crude fiber ${ }^{e}$ & 38.6 & 40.1 & 39.5 & 38.9 & 39.1 & 43.6 & 42.4 & 42.9 \\
\hline Crude fat $\mathrm{e}^{\mathrm{e}}$ & 62.1 & 52.7 & 52.2 & 53.6 & 51.9 & 44.3 & 44.1 & 44.6 \\
\hline Ash $^{e}$ & 41.2 & 42.6 & 42.1 & 43.6 & 38.6 & 41.6 & 42.2 & 41.8 \\
\hline Dry matter ${ }^{\mathrm{e}}$ & 888.6 & 892.4 & 894.3 & 885.6 & 886.9 & 885.1 & 886.8 & 884.1 \\
\hline
\end{tabular}

Notes: a Contained (per kg) retinyl acetate $3.75 \mathrm{mg}$, I,25-hydroxy-cholecalciferol $4 \mathrm{mg}$, DL- $\alpha$-tocopheryl acetate $30 \mathrm{mg}$, menadione $4 \mathrm{mg}$, thiamine propyl disulfide $3 \mathrm{mg}$, riboflavin tetrabutyrate $8 \mathrm{mg}$, riboflavin tetrabutyrate $8 \mathrm{mg}$, methylcobalamin $0.025 \mathrm{mg}$, sodium pantothenate $15 \mathrm{mg}$, pyridoxine $5 \mathrm{mg}$, niacin $60 \mathrm{mg}$, biotin $0.2 \mathrm{mg}$, and folic acid $2 \mathrm{mg}$; contained (mg/kg) copper (5), iron (I5), manganese (30), zinc (25), selenium (0.25), iodine (2), and chromium (0.25) as yeast-protein chelate; ${ }^{b}$ coccidiostat; cfiller material; ${ }^{d}$ calculated values; eanalyzed values. Feed enzymes (phytase and carbohydrases) and zinc bacitracin were added on top of all the diets. Calculated and analyzed nutrient values $\mathrm{g} / \mathrm{kg}$ unless stated otherwise.

Abbreviations: PC, positive control; NC, negative control; Bet I.3, supplemented with $1.3 \mathrm{~g} / \mathrm{kg}$ betaine hydrochloride; Bet 2.0 , supplemented with $2 \mathrm{~g} / \mathrm{kg}$ betaine hydrochloride. 
(days 1-38) period. All birds were slaughtered on day 38 following a 12-hour fast. The birds were mechanically stunted followed by exsanguination. The carcass was then scalded, plucked, and eviscerated. Carcass yield corresponded to carcass weight without shanks, head, neck, wings, viscera, or giblets. Yield of the breast, legs, and back were recorded and expressed as a percentage of live weight.

Deep-body temperature was measured at $12 \mathrm{pm}$ on days $14,21,28$ and 35 using a digital thermometer (accuracy $\pm 0.1^{\circ} \mathrm{C}$ ) inserted approximately $5 \mathrm{~cm}$ deep into the rectum. Respiratory rates were measured by counting the panting breaths of a bird for 30 seconds, and this value was multiplied by two to obtain the number of breaths per minute.

Blood samples for metabolite and hormone assays were collected on day 38 after a 12-hour fast. Approximately $5 \mathrm{~mL}$ of whole blood was collected from jugular veins into Vacutainer tubes without any anticoagulant. The tubes were kept in ice immediately after collection for an hour for separation of serum. The cells were further separated by centrifugation at $2,500 \times g$ for 10 minutes, and the serum was preserved at $-20^{\circ} \mathrm{C}$ till analyzed. A commercial kit was used to estimate serum $\mathrm{CO}_{2}$ (Biosino Bio-Technology and Services Inc., Changping, People's Republic of China [PRC]), and the test was based on the principle that phosphoenolpyruvate reacts with the bicarbonate present in serum to form oxaloacetate, which then reacts with and oxidizes an $\mathrm{NADH}+\mathrm{H}^{+}$analog in the presence of malate dehydrogenase. The reduction in the concentration of the NADH + $\mathrm{H}^{+}$analog, which was proportional to the concentration of $\mathrm{CO}_{2}$ in blood, was measured photometrically to interpret the results. Serum triacylglycerol was estimated by a commercial kit (Diasis Diagnostik Sistemler, Istanbul, Turkey) in a semiautomatic blood-biochemistry analyzer (RT-9200; Rayto Life and Analytical Sciences Co Ltd, Shenzhen, PRC). Concentrations of triiodothyronine $\left(\mathrm{T}_{3}\right)$, thyroid-stimulating hormone (TSH), and corticosterone were determined by enzyme-linked immunoassays with commercial kits (United Biotech Inc., Sunnyvale, CA, USA). All tests were performed in duplicate, and results with intra-assay variations exceeding $5 \%$ were rejected.

\section{Statistical analyses}

Means and standard deviations were calculated for all quantitative data using the cages as the experimental units, and the treated and control groups were compared using a one-way analysis of variance (ANOVA), with the exception of body weight, rectal temperature, and respiration-rate data, which were compared using a two-way repeated-measure
ANOVA. The primary data analysis was done with SPSS version 17.0 (SPSS Inc., Chicago, IL, USA). When the results of ANOVAs were statistically significant, a Tukey's test for multiple comparisons was performed to compare results of all groups. When variances were significantly different by Bartlett's test, groups were compared using a nonparametric method (Kruskal-Wallis nonparametric ANOVA). The critical value for significance of all comparisons was $P<0.05$. To estimate the dose response of betaine $\mathrm{HCl}$, polynomial contrasts were applied when a significant mean difference was obtained, and the values are expressed as linear and quadratic responses.

\section{Results}

The ingredients and chemical composition of the experimental diets are presented in Table 1. Metabolizable energy in both the starter and grower diets was lower by $200 \mathrm{KJ} / \mathrm{kg}$ in the NC, Bet 1.3, and Bet 2.0 groups compared with the PC. The other constituents, including the amino acids except methionine, were similar in all the diets.

The mean temperature in the experimental room was close to the values recommended for Cobb broiler chickens only up to the second week of age. The mean daytime temperature measured at $2 \mathrm{pm}$ was always higher than the standard, and as the experiment progressed, the difference between the suggested and the observed temperature widened (Figure 1). The RH in the experimental room (Figure 2) was $29 \%-44 \%$ higher than that suggested for Cobb broilers.

Rectal temperature (Figure 3 ) was similar across the diets at day $14(P>0.05)$ and higher at days 21 and 28 in the PC and NC groups compared to that in the Bet 1.3 and Bet 2.0 groups $(P<0.05)$. The NC group had a lower rectal temperature than the PC group till day 28, and unlike the PC group, where the temperature increased steeply, the rise in temperature was

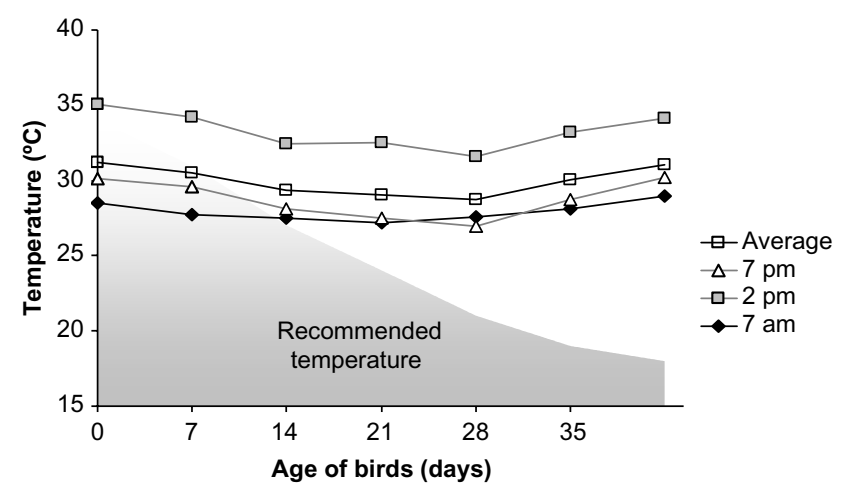

Figure I Experimental room temperature $\left({ }^{\circ} \mathrm{C}\right)$ measured at different time points in a day. 


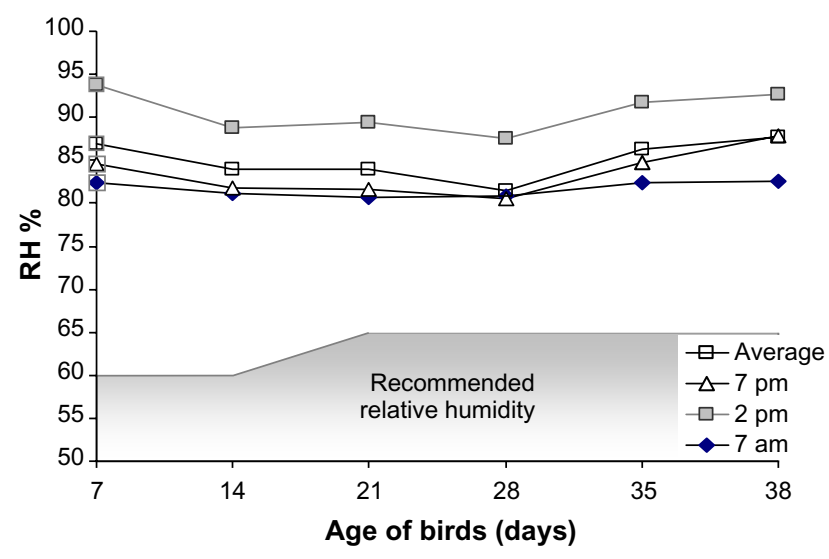

Figure 2 Relative humidity $(\mathrm{RH} ; \%)$ in the experimental room measured at different time points in a day.

more gradual in the former. Rectal temperature in the PC and $\mathrm{NC}$ groups started declining after 28 days of age, and at the time of the final measurement (day 35) the difference between the groups was minimal. The respiration rate (Figure 4) in the different dietary groups was in accord with the rectal temperature, and was higher in the $\mathrm{PC}$ and $\mathrm{NC}$ groups than both the betaine-supplemented groups, particularly at days 21 and 28. In the PC and NC groups, the respiration rate dipped after day 28 and at day 35 , the difference between the dietary groups was insignificant. In the Bet 1.3 group, respiration showed an increasing trend during days $21-35$, and in the Bet 2.0 group the respiration rate was on a downward trend during days 28-35. Panting occurred in all groups during

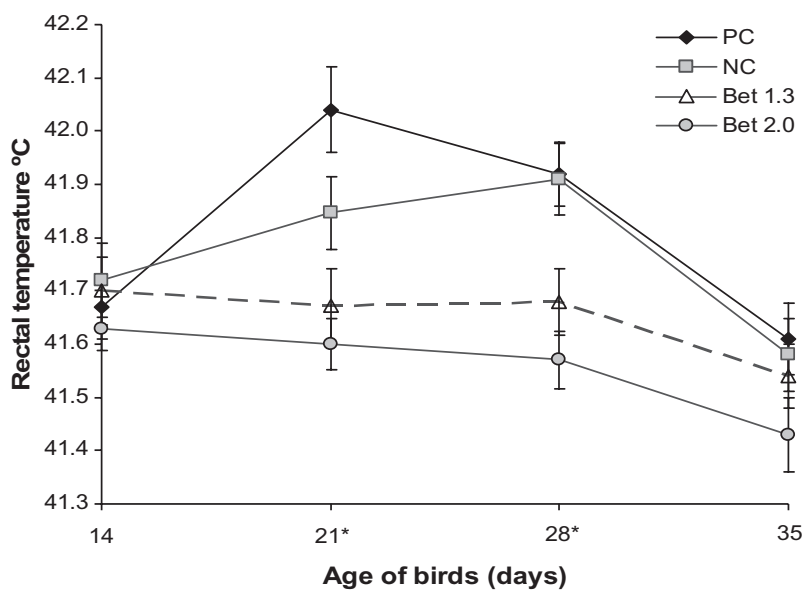

Figure 3 Rectal temperatures of experimental broilers fed diets containing different levels of methionine, choline, and betaine hydrochloride and exposed to thermal stress.

Notes: Means of eight replicate cages in each treatment ( $n=4$ birds in each cage); *rectal temperature was significantly lower $(P<0.05)$ in the Bet 1.3 and Bet 2.0 groups compared with the PC and NC groups at 21 and 28 days of age.

Abbreviations: PC, positive control (diet contained $2.7 \mathrm{~g} / \mathrm{kg}$ DL-methionine and $\mathrm{I} \mathrm{g} / \mathrm{kg}$ choline chloride [60\%]); NC, negative control (diet contained $1.8 \mathrm{~g} / \mathrm{kg} \mathrm{DL}$ methionine and no added choline chloride); Bet I.3, NC + I.3 g/ $/ \mathrm{kg}$ betaine $\mathrm{HCL}$; Bet 2.0, $\mathrm{NC}+2.0 \mathrm{~g}$ betaine $\mathrm{HCL}$.

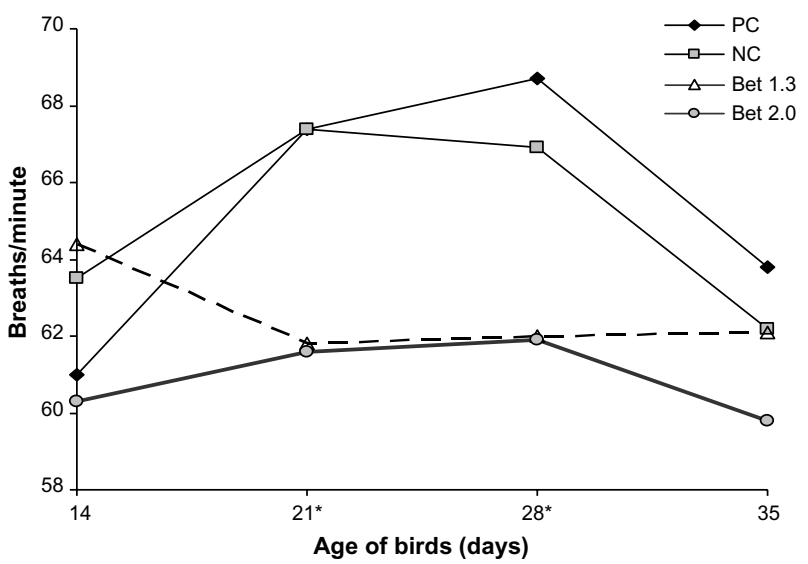

Figure 4 Variation in respiration rate (breaths/minute) of experimental broilers fed diets containing different levels of methionine, choline, and betaine hydrochloride and exposed to thermal stress.

Notes: Means of eight replicate cages in each treatment ( $n=4$ birds in each cage); *respiration rate was significantly lower $(P<0.05)$ in the Bet 1.3 and 2.0 groups compared with the other dietary groups at 21 days of age, and at 28 days of age the Bet 2.0 group showed a lower $(P<0.05)$ respiration rate than the rest of the dietary groups.

Abbreviations: PC, positive control (diet contained $2.7 \mathrm{~g} / \mathrm{kg}$ DL-methionine and $\mathrm{I} \mathrm{g} / \mathrm{kg}$ choline chloride [60\%]); NC, negative control (diet contained I.8 g/kg DLmethionine and no added choline chloride); Bet I.3, NC + I.3 g/ kg betaine HCL; Bet 2.0, $\mathrm{NC}+2.0 \mathrm{~g}$ betaine $\mathrm{HCL}$.

the day, when both ambient temperature and $\mathrm{RH}$ were on the higher side. The intensity of panting declined at night, when ambient temperature decreased.

Performance data presented in Table 2 indicate that across the diets, live weight at day 16 was better in the Bet 2.0 group $(P<0.001)$. Betaine at both levels of inclusion improved feed intake $(P<0.001)$ compared with the NC group. There was a quadratic effect of supplemental betaine on FCR, which caused a poorer FCR in the Bet 1.3 group compared with the rest of the treatments $(P<0.05)$. During 17-38 days of age, neither feed intake nor FCR was affected by dietary betaine supplementation. However, the birds supplemented with $1.3 \mathrm{~g}$ betaine $\mathrm{HCl} / \mathrm{kg}$ feed gained more body weight compared to those in the $\mathrm{PC}, \mathrm{NC}$, and Bet 2.0 groups $(P<0.05)$. The effect of supplemental betaine was found to be quadratic $(P<0.05)$, and the birds in the Bet 1.3 group gained more body weight than those in the Bet 2.0 group. Overall (days 1-38), the birds in both betaine-supplemented groups had better body weight and body-weight gain $(P<0.05)$, and the level of betaine in the diet exerted a linear effect on these parameters $(P<0.05)$. Feed intake during days 1-38 improved linearly with the dose of supplemental betaine $(P<0.001)$. The FCR was similar across the groups $(P>0.05)$. There was no mortality during days 1-16, but during days 17-38 some mortality occurred in the $\mathrm{NC}$ and Bet 1.3 groups, taking the overall livability values to $100 \%, 96.9 \%, 93.8 \%$, and $100 \%$ respectively in the $\mathrm{PC}, \mathrm{NC}$, Bet 1.3, and Bet 2.0 groups. 
Table 2 Performance of broilers fed varied levels of methionine, choline, and betaine hydrochloride and exposed to thermal stress: during $1-16$ days of age ${ }^{d}$

\begin{tabular}{|c|c|c|c|c|c|c|c|}
\hline \multirow[t]{2}{*}{ Attributes } & \multicolumn{4}{|c|}{ Dietary treatments } & \multirow{2}{*}{$\begin{array}{l}\text { Standard } \\
\text { error of mean }\end{array}$} & \multicolumn{2}{|c|}{ Significance, $P$-value } \\
\hline & PC & NC & Bet I.3 & Bet 2.0 & & Diet & Betaine \\
\hline \multicolumn{8}{|l|}{ Days I-16 } \\
\hline Live weight gain, $g$ & $513.6^{\mathrm{a}}$ & $494.9^{a}$ & $501.7^{\mathrm{a}}$ & $549.3^{b}$ & 5.44 & $* * *$ & $* * *, \mathrm{~L}$ \\
\hline Feed intake, $g$ & $568.4^{\mathrm{b}}$ & $539.2^{\mathrm{a}}$ & $594.2^{c}$ & $606.6^{c}$ & 6.01 & $* * *$ & $* * *, \mathrm{~L}$ \\
\hline FCR & $1.108^{\mathrm{a}}$ & $1.093^{\mathrm{a}}$ & $1.186^{b}$ & $1.106^{\mathrm{a}}$ & 0.013 & $*$ & $* * *, Q$ \\
\hline \multicolumn{8}{|l|}{ Days 17-38 } \\
\hline Live weight gain, $\mathrm{g}$ & $1,286.5^{a}$ & $1,305.9^{a, b}$ & $1,342.9^{b}$ & $|, 3| \mid .3^{a, b}$ & 7.33 & $*$ & $*, Q$ \\
\hline Feed intake, $g$ & $2,408.8$ & $2,404.1$ & $2,409.2$ & $2,407.1$ & 0.93 & NS & NS \\
\hline FCR & 1.875 & 1.842 & 1.795 & 1.837 & 0.011 & NS & NS \\
\hline \multicolumn{8}{|l|}{ Days I-38 } \\
\hline Live weight, g & $\mathrm{I}, 843 . \mathrm{I}^{\mathrm{a}}$ & $\mathrm{I}, 843.8^{\mathrm{a}}$ & $\mathrm{I}, 887.7^{\mathrm{b}}$ & $1,903.6^{b}$ & 8.44 & $*$ & $* *, \mathrm{~L}$ \\
\hline Live weight gain, $\mathrm{g}$ & $\mathrm{I}, 800 . \mathrm{I}^{\mathrm{a}}$ & $\mathrm{I}, 800.8^{\mathrm{a}}$ & $\mathrm{I}, 844.7^{\mathrm{b}}$ & $1,860.6^{b}$ & 8.45 & $*$ & $* *, \mathrm{~L}$ \\
\hline Feed intake, $g$ & $2,977.2^{b}$ & $2,943.3^{a}$ & $3,003.5^{c}$ & $3,013.6^{c}$ & 6.17 & $* * *$ & $* * *, \mathrm{~L}$ \\
\hline FCR & 1.665 & 1.635 & 1.629 & 1.62 & 0.007 & NS & NS \\
\hline
\end{tabular}

Notes: Means bearing dissimilar letters in superscript varied significantly $\left({ }^{*} P<0.05, * * P<0.01, * * * P<0.001\right)$; ${ }^{d}$ means of eight replicate cages in each treatment ( $\mathrm{d}=4$ birds in each cage); ${ }^{a, b, c}$ Significant differences. Llinear effect; Qquadratic effect.

Abbreviations: PC, positive control (diet contained $2.7 \mathrm{~g} / \mathrm{kg}$ DL-methionine and I g/kg choline chloride [60\%]); NC, negative control (diet contained I.8 g/kg DL-methionine and no added choline chloride); Bet I.3, NC + $1.3 \mathrm{~g} / \mathrm{kg}$ betaine HCL; Bet 2.0, NC + $2.0 \mathrm{~g}$ betaine HCL; FCR, feed-conversion ratio; NS, not significant.

Carcass traits were unaffected by diets (Table 3). However, there was a linear effect of the dietary level of betaine on dressed carcass weight $(P<0.05)$, which was $3.74 \%$ and $8.18 \%$ higher in the Bet 1.3 and Bet 2.0 groups, respectively, compared to the $\mathrm{PC}$.

Betaine supplementation had conspicuous effects on serum biochemical traits and hormonal parameters (Table 4). Serum $\mathrm{CO}_{2}$ was lower in the $\mathrm{NC}$ and the Bet 2.0 groups than the $\mathrm{PC}$ and the Bet 1.3 groups $(P<0.01)$. Dietary betaine level had a quadratic effect on serum $\mathrm{CO}_{2}$ concentration, and the Bet 1.3 group showed higher serum $\mathrm{CO}_{2}$ levels than the Bet 2.0 group $(P<0.01)$. Betaine at $2.0 \mathrm{~g} / \mathrm{kg}$ decreased $(P<0.01)$ serum triacylglycerol compared with the other dietary groups, and this response was linear with the inclusion level of betaine in $\operatorname{diet}(P<0.01)$. Betaine supplementation linearly increased the concentration of $\mathrm{T}_{3}$ and TSH in serum $(P<0.001)$, and across the diets $\mathrm{T}_{3}$ and TSH concentrations were higher in the Bet 2.0 group $(P<0.001)$. Serum corticosterone was lower in the $\mathrm{NC}$ group compared with the rest of the dietary treatments $(P<0.01)$, and supplemental betaine had little effect on this parameter $(P>0.05)$.

\section{Discussion}

Rectal temperature and respiration rate of the experimental broilers revealed that the condition of the experimental room exerted sufficient thermal stress on them. Differences between the observed and recommended room temperatures at days 21 , 28,35 , and 38 were $21 \%, 37 \%, 58 \%$, and $73 \%$, respectively. A high RH aggravated the stress further, and the impact was perhaps more in the younger chickens, because the difference between the observed and the suggested values were wider up to day 21. It was this thermal stress that did not allow the birds in all the treatment groups to achieve the standard body weight, an observation that has already been reported..$^{26,27}$

Rectal temperature suggested that betaine supplementation at both the dose levels blunted the heat-stress response after day 21, while the PC group of birds could manage this stress only after 28 days of age. Rectal temperature may be

Table 3 Carcass yields in broilers fed varied levels of methionine, choline, and betaine hydrochloride and exposed to thermal stress ${ }^{d}$

\begin{tabular}{|c|c|c|c|c|c|c|c|}
\hline \multirow[t]{2}{*}{ Attributes } & \multicolumn{4}{|c|}{ Dietary treatments } & \multirow{2}{*}{$\begin{array}{l}\text { Standard } \\
\text { error of mean }\end{array}$} & \multicolumn{2}{|c|}{$P$-value (main effects) } \\
\hline & PC & NC & Bet I.3 & Bet 2.0 & & Diet & Betaine \\
\hline Carcass yielde & $66.8^{\mathrm{b}}$ & $65.7^{a}$ & $66.2^{\mathrm{a}, \mathrm{b}}$ & $67.6^{c}$ & 0.27 & NS & $*, \mathrm{~L}$ \\
\hline Breast & 19.5 & 19.1 & 18.6 & 19.1 & 0.22 & NS & NS \\
\hline Legs & 20.1 & 18.1 & 19.2 & 18.9 & 0.19 & NS & NS \\
\hline Back & 16.37 & 15.46 & 15.33 & 15.55 & 0.22 & NS & NS \\
\hline
\end{tabular}

Notes: Means bearing dissimilar letters in superscript varied significantly $(* P<0.05)$; ${ }^{d}$ means of eight replicate cages in each treatment $\left(\mathrm{n}=4\right.$ birds in each cage); ${ }^{\mathrm{e}} \mathrm{excluding}$ shanks, neck, wings, viscera, and giblets; a,b,c Significant differences. Llinear effect.

Abbreviations: PC, positive control (diet contained $2.7 \mathrm{~g} / \mathrm{kg}$ DL-methionine and I g/kg choline chloride [60\%]); NC, negative control (diet contained I.8 g/kg DL-methionine and no added choline chloride); Bet $1.3, \mathrm{NC}+1.3 \mathrm{~g} / \mathrm{kg}$ betaine $\mathrm{HCL} ;$ Bet 2.0, NC $+2.0 \mathrm{~g}$ betaine $\mathrm{HCL} ; \mathrm{NS}$, not significant. 
Table 4 Metabolites and hormones in serum of broilers (38 days) fed varied levels of methionine, choline, and betaine hydrochloride and exposed to thermal stress ${ }^{d}$

\begin{tabular}{|c|c|c|c|c|c|c|c|}
\hline \multirow[t]{2}{*}{ Attributes } & \multicolumn{4}{|c|}{ Dietary treatments } & \multirow[t]{2}{*}{$\begin{array}{l}\text { Standard } \\
\text { error of mean }\end{array}$} & \multicolumn{2}{|c|}{$\begin{array}{l}\text { P-value (main } \\
\text { effects) }\end{array}$} \\
\hline & PC & NC & Bet I.3 & Bet 2.0 & & Diet & Betaine \\
\hline Carbon dioxide, $\mathrm{mmol} / \mathrm{L}$ & $41.74^{c}$ & $28.33^{\mathrm{a}}$ & $42.56^{c}$ & $35.48^{b}$ & 1.19 & ** & $* *, Q$ \\
\hline Triacylglycerol mmol/L & $1.426^{\mathrm{b}}$ & $1.50 \mathrm{I}^{\mathrm{b}}$ & $1.438^{\mathrm{b}}$ & $1.027^{\mathrm{a}}$ & 0.043 & $* * *$ & $* *, \mathrm{~L}$ \\
\hline $\mathrm{TSH}, \mu \mathrm{U} / \mathrm{mL}$ & $0.665^{\mathrm{a}}$ & $0.704^{\mathrm{a}}$ & $1.595^{\mathrm{b}}$ & $1.933^{c}$ & 0.105 & $* * *$ & $* * *, \mathrm{~L}$ \\
\hline $\mathrm{T}_{3}, \mathrm{nmol} / \mathrm{L}$ & $2.79^{b}$ & $2.19^{a}$ & $2.78^{b}$ & $3.14^{c}$ & 0.19 & $* * *$ & $* *, \mathrm{~L}$ \\
\hline Corticosterone, $\mathrm{ng} / \mathrm{mL}$ & $189.49^{b}$ & $159.32^{\mathrm{a}}$ & $207.96^{\mathrm{b}}$ & $207.67^{\mathrm{b}}$ & 0.39 & ** & NS \\
\hline
\end{tabular}

Notes: Means bearing dissimilar letters in superscript varied significantly $\left(* * P<0.01,{ }^{* * *} P<0.001\right)$; ${ }^{d}$ means of eight replicate cages in each treatment $(\mathrm{n}=4$ birds in each cage); a,b,csignificant differences. Llinear effect, Qquadratic effect.

Abbreviations: PC, positive control (diet contained $2.7 \mathrm{~g} / \mathrm{kg}$ DL-methionine and I g/kg choline chloride [60\%]); NC, negative control (diet contained I.8 g/kg DL-methionine and no added choline chloride); Bet I.3, NC + $1.3 \mathrm{~g} / \mathrm{kg}$ betaine $\mathrm{HCL}$; Bet 2.0, NC + $2.0 \mathrm{~g}$ betaine $\mathrm{HCL}$; $\mathrm{T}_{3}$, triiodothyronine; NS, not significant.

considered one of the indicators of metabolic rate in broilers, and increases when birds are exposed to high ambient temperature. Betaine supplementation reportedly helps in reducing body temperature to some extent. ${ }^{27,28} \mathrm{~A}$ lower rectal temperature in the $\mathrm{NC}$ group up to day 28 may be explained by a retarded metabolic rate in that group caused by suboptimal levels of dietary methionine and energy. This also helps in explaining the retarded growth rate in this group. Contrary to the general tendency of the broilers, the birds in the $\mathrm{NC}$ group did not attempt to increase feed intake in order to compensate for the deficient nutrients in diets like methionine and energy. ${ }^{29}$ Probably, the stress was too severe for the birds to respond to by increasing feed intake. Chickens' ability to regulate body temperature during the posthatch period increases with age through neural and hormonal interactions and through epigenetic adaptations. ${ }^{30,31}$ In the early posthatch period, chicks behave more as a poikilotherm than a homeotherm up to 10 days of age, and it is believed that exposure to heat stress at this early period of life makes the chicken more heat-tolerant during the final rearing period, when endogenous heat production is high due to the high metabolic rate..$^{31-33}$ The current findings partially corroborated this hypothesis, since it was observed in this study that rectal temperature in the $\mathrm{PC}$ groups started declining at a later age after a steep initial rise.

One of the key indicators of heat stress is a decline in feed intake by about $1 \%$ for each $1{ }^{\circ} \mathrm{C}$ increase in temperature from the bird's comfort zone, and this decline may be as high as $30 \%$ at an ambient temperature of $32^{\circ} \mathrm{C} .{ }^{34}$ It was observed that under situations of constant temperatures of $25^{\circ} \mathrm{C}$ and $35^{\circ} \mathrm{C}$ and a cycling temperature of $30^{\circ} \mathrm{C}-40^{\circ} \mathrm{C}$, feed intake and growth rate of broilers decreased by $15.9 \%$ and $12.3 \%$, respectively, at $35^{\circ} \mathrm{C}$ and by $14.9 \%$ and $12.5 \%$, respectively, under cyclical heat stress compared to those at $25^{\circ} \mathrm{C}$. In the present experiment also, feed intake was severely depressed, and compared to the breed standard, feed intake was lower by $21 \%$ in the NC group and $17 \%$ in the PC group at 16 days. Betaine supplementation alleviated the stress partially, since the depression in feed intake in both the betaine-supplemented groups was less than that in the $\mathrm{PC}$ and $\mathrm{NC}$ groups, and the variation with the breed standard was between $12 \%$ and $14 \%$. This was in agreement with earlier observations indicating beneficial effects of betaine supplementation in thermally stressed broiler chickens. ${ }^{21,35,36}$ However, during days 17-38, there was a subtle effect of supplemental betaine on feed consumption, indicating little effect of betaine on feed intake in older birds. ${ }^{37,38}$ Nevertheless, unlike some earlier reports, betaine supplementation at both the dose levels improved feed intake in this study. ${ }^{21,39,40}$ Live weight improved by more than 3\% over the PC and NC groups in the Bet 2.0 group, which suggests that at this level of inclusion betaine not only compensated for methionine but also contributed a substantial amount of energy to support this growth process. Feed conversion also improved over the PC group by 3.6 and 4.5 points, respectively, in the Bet 1.3 and Bet 2.0 groups. This improvement in FCR are of substantial commercial value, especially in regions where broilers are reared in open housing systems and thus are exposed to extremes of temperature. Unlike many other experiments evaluating the effects of betaine in broilers exposed to cyclical heat stress, in the current study the birds were exposed to critical thermal stress from the beginning till the end of the trial. Therefore, the impact of the stress and the effect of supplemental betaine might be quite different from other studies.

Serum $\mathrm{CO}_{2}$ is a measure of metabolic activities of birds, and its higher concentration in the blood suggests greater metabolic activity and may be considered as an indicator of panting. A negative correlation between cloacal temperature and blood $\mathrm{CO}_{2}$ levels has been reported. ${ }^{41}$ Respiratory frequency and evaporative water loss through panting are 
linearly related, and they increase with ambient temperature above the panting threshold. ${ }^{42}$ Panting is an energyconsuming response in a hot environment, reduces retention of metabolizable energy, and affects growth. ${ }^{43}$ When the respiration rate and serum $\mathrm{CO}_{2}$ levels were correlated, it appeared that betaine at $2 \mathrm{~g} / \mathrm{kg}$ feed decreased panting. Also, at this level of inclusion, betaine alleviated thermal stress to a greater extent, which was not possible with the lower dose. This was evidenced from a lower respiration rate but higher serum $\mathrm{CO}_{2}$ level in the Bet 1.3 group. The level of serum $\mathrm{CO}_{2}$ correlated well with the trend observed with the cloacal temperature over the period of time in all the groups except the NC. However, the patterns of rectal temperature, respiration rate, and body-weight gain in the NC group were indicative of a lower metabolic rate, and may explain the lower serum $\mathrm{CO}_{2}$ level in this group.

Serum triacylglycerol decreased when betaine was supplemented at a rate of $2 \mathrm{~g} / \mathrm{kg}$ feed, but not at $1.3 \mathrm{~g} / \mathrm{kg}$ feed. Reports in this regard are scarce, and most of the available literature indicates little effect of supplemental betaine on serum triacylglycerol. ${ }^{38,44}$ However, betaine supplementation may decrease serum triacylglycerol concentration due to the fact that the hormone-sensitive lipase activity, which catabolizes triacylglycerol to yield energy, decreases with betaine supplementation. ${ }^{40,45}$

Betaine supplementation elevated serum levels of $\mathrm{T}_{3}$ and $\mathrm{TSH}$, albeit with a different dose response. The activity of thyroid hormones is negatively correlated with ambient temperature, and at high ambient temperatures the activity of thyroid hormones declines to depress performance of birds. Based on the relationship of thyroid secretion rate to growth demonstrated in chickens, it is possible that the poorer performance in the control group of birds was due partly to the decreased $\mathrm{T}_{3}$ activity. ${ }^{46,47}$

High level of corticosteroids in the blood is one of the indicators of stress in broilers. ${ }^{48}$ Thermal stresses induce release of corticotropin-releasing hormone and synthesis of corticosteroids, which ensure the maintenance of homeostasis and recovery from stress. ${ }^{49}$ In laying hens reared under moderately high environmental temperature (maximum $\left.27^{\circ} \mathrm{C}\right)$, betaine supplementation $(0.7$ and $1.5 \mathrm{~g} / \mathrm{kg})$ reduced plasma corticosteroid, ${ }^{50}$ which might have been due to the positive effect of betaine on nitric oxide production, which in turn might inhibit the biosynthesis of glucocorticoid. ${ }^{51,52}$ However, in the present study, betaine supplementation did not influence serum corticosterone level. This suggests that betaine elicited its stress-alleviation effect not via the corticosterone-mediated pathway.
The present investigation suggests that betaine can replace all of the added choline from the dietary regimen of heat-stressed broiler chickens with little negative impact on performance. The methionine-sparing effect of choline was not studied, since the role of choline in this regard is questionable. ${ }^{24}$ The ability of betaine to spare the methionine need of broiler chickens is subject to substantial controversy, and generally it is agreed that supplemental betaine may improve broiler performance only in conditions of stress in broilers that are fed with diets containing suboptimal levels of methionine. ${ }^{24,53-55}$ Betaine supplements in diets deficient in methionine reportedly improved digestibility of starch, and when challenged with coccidia, improved digestibility was observed for other nutrients also. ${ }^{54}$ It is argued that for betaine to elicit any discernible effect, a minimum level of methionine should be present in the diet, and this level may vary between 15 and $20 \mathrm{mg}$ methionine per kilogram of diet. ${ }^{55-57}$ However, all these studies were conducted with natural betaine. The current study added to the existing pool of knowledge by revealing the fact that a similar response may be obtained with betaine $\mathrm{HCl}$ too, although a higher dose of $2 \mathrm{~g} / \mathrm{kg}$ may be required to obtain a desired level of performance.

\section{Conclusion}

Based on these data, it was concluded that like natural betaine, synthetic betaine HCL ( $2 \mathrm{~g} / \mathrm{kg}$ diet) may be used as a tool to improve performance of broilers under thermal stress conditions. Supplementation of betaine $\mathrm{HCl}$ supported the metabolic processes of the birds exposed to thermal stress and thus sustained a better growth rate. Partial removal of added DL-methionine and total removal of choline was found not to have any discernible negative effect on live weight and FCR. Therefore, on the basis of the present data, it may be concluded that supplementation of broiler diets with betaine hydrochloride may successfully ameliorate the negative impacts of thermal stress in broilers. Also, it may be possible to assign some methionine and energy matrix to supplemental betaine, considering the methionine- and energy-sparing effects of betaine obtained in this study, which may be used effectively as a tool in the process of least-cost feed formulation.

\section{Disclosure}

The authors report no conflicts of interest in this work.

\section{References}

1. Mujahid A, Akiba Y, Toyomizu M. Acute heat stress induces oxidative stress and decreases adaptation in young white leghorn cockerels by downregulation of avian uncoupling protein. Poult Sci. 2007;86: 364-371. 
2. Beard CW, Mitchell BW. Influence of environmental temperatures on the serological responses of broiler chickens to inactivated and viable Newcastle disease vaccines. Avian Dis. 1987;31:321-326.

3. Rosales AG. Managing stress in broiler breeders: a review. J Appl Poul Res. 1994;3:199-207.

4. Beck JR. Understanding and minimizing stress in broilers and broiler breeders. Zootecnica Int. 1991;15:30-38.

5. Gross WB, Siegel PB. Long-term exposure of chickens to three levels of social stress. Avian Dis. 1981;25:312-325.

6. Freeman BM. The stress syndrome. Worlds Poult Sci J. 1987;43:15-19.

7. Holik V. Management of laying hens to minimize heat stress. Lohmann Inf. 2009;44:16-29.

8. Dei HK, Bumbie GZ. Effect of wet feeding on growth performance of broiler chickens in a hot climate. Br Poult Sci. 2011;52:82-85.

9. Mahmoud UT, Abdel-Rahman MA, Darwish MH. Effects of propolis, ascorbic acid and vitamin $\mathrm{E}$ on thyroid and corticosterone hormones in heat stressed broilers. J Adv Vet Res. 2014;4:18-27.

10. Rosa PS, Faria Filho DE, Dahlke F, Vieira BS, Macari M, Furlan RL. Performance and carcass characteristics of broiler chickens with different growth potential and submitted to heat stress. Rev Bras Cienc Avic. 2007;9:181-186.

11. Geraert PA, Padilha JC, Guillaumin S. Metabolic and endocrine changes induced by chronic heat exposure in broiler chickens: growth performance, body composition and energy retention. Br J Nutr. 1996;75: 195-204.

12. Koh K, Macleod MG. Effects of ambient temperature on heat increment of feeding and energy retention in growing broilers maintained at different food intakes. Br Poult Sci. 1999;40:511-516.

13. Deaton JW, Reece FN, Lott BD. Effect of atmospheric ammonia on laying hens performance. Poult Sci. 1982;61:1815-1817.

14. Faria Filho DE, Campos DM, Alfonso-Torres KA, et al. Protein levels for heat-exposed broilers: performance, nutrients digestibility, and energy and protein metabolism. Int J Poult Sci. 2007;6:187-194.

15. Ain-Baziz H, Geraert PA, Padilha JC, Guillaumin S. Chronic heat exposure enhances fat deposition and modifies muscle and fat partition in broiler carcasses. Poult Sci. 1996;75:505-513.

16. Ratriyanto A, Mosenthin R, Bauer E, Eklund M. Metabolic, osmoregulatory and nutritional functions of betaine in monogastric animals. Asian-Australas J Anim Sci. 2009;22:1461-1476.

17. Eklund M, Bauer E, Wamatu J, Mosenthin R. Potential physiological and nutritional functions of betaine in livestock. Nutr Res Rev. 2005;18: 31-48.

18. Kidd MT, Ferket PR, Garlich JD. Nutritional and osmoregulatory functions of betaine. Worlds Poult Sci J. 1997;53:125-139.

19. Siljander-Rasi H, Peuranen S, Tiihonen K, et al. Effect of equimolecular dietary betaine and choline addition on performance, carcass quality and physiological parameters of pigs. Anim Sci. 2003;76:55-62.

20. European Food Safety Authority. Scientific opinion on the safety and efficacy of aliphatic and aromatic amines (chemical group 33) when used as flavourings for all animal species. EFSA J. 2012;10:2679.

21. Sakomura NK, Barbosa NA, Longo FA, Da Silva EP, Bonato MA, Fernandez JB. Effect of dietary betaine supplementation on the performance, carcass yield and intestinal morphometrics of broilers submitted to heat stress. Rev Bras Cienc Avic. 2013;15:105-112.

22. Pesti GM, Benevenga NJ, Harper AE, Sunde ML. Factors influencing the assessment of the availability of choline in feedstuffs. Poult Sci. 1981;60:188-196.

23. Paniz C, Grotto D, Schmitt GC, et al. Fisiopatologia da deficiência de vitamina B12 e seu diagnóstico laboratorial. J Bras Patol Med Lab. 2005;41:323-334.

24. Waldroup PW, Motl MA, Yan F, Fritts CA. Effect of betaine and choline on response to methionine supplementation to broiler diets formulated to industry standards. J Appl Poult Res. 2006;15:58-71.

25. Sun H, Yang WR, Yang ZB, Wang Y, Jiang SZ, Zhang GG. Effects of betaine supplementation to methionine deficient diet on growth performance and carcass characteristics of broilers. Am J Anim Vet Sci. 2008;3:78-84.
26. Khattak FM, Acamovic T, Sparks N, et al. Comparative efficacy of different supplements used to reduce heat stress in broilers. PakJ Zool. 2012;44:31-41.

27. Sayed MA, Downing J. Effects of dietary electrolyte balance and addition of electrolyte-betaine supplements in feed or water on performance, acid-base balance and water retention in heat-stressed broilers. Br Poult Sci. 2015;56:195-209.

28. Fernandes JIM, Scapini LB, Gottardo ET, Burnin AM Jr, dos Santos Marques FE, Gruchouskei L. Thermal conditioning during the first week on performance, heart morphology and carcass yield of broilers submitted to heat stress. Acta Sci Anim Sci. 2013;35:311-319.

29. Bowmaker JE, Gous RM. The response of broiler breeder hens to dietary lysine and methionine. Br Poult Sci. 1991;32:1069-1088.

30. Debonne M, Baarendse PJJ, van Den Brand H, Kemp B, Bruggeman V, Decuypere E. Involvement of the hypothalamic-pituitary-adrenal axis in the ontogeny of avian thermoregulation: a review. Worlds Poultry Sci J. 2008;64:309-321.

31. Nichelmann M, Tzschentke B. Ontogeny of thermoregulation in precocial birds. Comp Biochem Physiol A Mol Integr Physiol. 2002;131: 751-763.

32. van den Brand H, Molenaar R, van der Star I, Meijerhof R. Early feeding affects resistance against cold exposure in young broiler chickens. Poult Sci. 2010;89:716-720.

33. Tan GY, Yang L, Fu YQ, Feng JH, Zhang MH. Effects of different acute high ambient temperatures on function of hepatic mitochondrial respiration, antioxidative enzymes, and oxidative injury in broiler chickens. Poult Sci. 2010;89:115-122.

34. Potter LM. Nutrition of poultry in hot climates. Zootecnica Int. 1985;5: 45-50.

35. Henken AM, Groote Schaarsberg AM, Vanderhel W. The effect of environmental temperature on immune response and metabolism of the young chicken. 4. Effect of environmental temperature on some aspects of energy and protein metabolism. Poult Sci. 1983;62: 59-67

36. Zulkifli I, Mysahra SA, Jin LZ. Dietary supplementation of betaine $\left(\right.$ Betafin $\left.^{\circledR}\right)$ and response to high temperature stress in male broiler chicken. Asian-Australas J Anim Sci. 2004;17:244-249.

37. Jahanian R, Rahmani HR. The effect of dietary fat level on the response of broiler chicks to betaine and choline supplement. $J$ Biol Sci. 2008;8:362-367.

38. Konca Y, Kinkpinar F, Mert S, Yaylak E. Effect of betaine on performance, carcass, bone and blood characteristics of broilers during natural summer temperatures. J Anim Vet Adv. 2008;7:930-937.

39. Esteve-Garcia E, Mack S. The effect of DL-methionine and betaine on growth performance and carcass characteristics in broilers. Anim Feed Sci Technol. 1999;87:85-93.

40. Zhan XA, Li XJ, Zhao Q. Effects of methionine and betaine supplement on growth performance, carcass composition and metabolism of lipids in male broilers. Br Poult Sci. 2006;47:576-580.

41. Pech-Waffenschmidt V, Bogin E, Avidar Y, Horst P. Metabolic and biochemical changes during heat stress in relation to the feathering degree of the domestic hen. Avian Pathol. 1995;24:33-44.

42. Richards SA. Evaporative water loss in domestic fowls and its partition in relation to ambient temperature. J Agric Sci. 1976;87:527-532.

43. Donkoh A. Ambient temperature: a factor affecting performance and physiological response in broiler chickens. Int J Biometeorol. 1989;33: 259-265.

44. Baghaei M, Eslami M, Chaji M, Mamoue M, Bojarpour M. Effect of different levels of DL-methionine replaced with Betafin on some blood parameters on broiler chickens. J Anim Vet Adv. 2011;10: 777-779.

45. He S, Zhao S, Dai S, Liu D, Bokhari SG. Effects of dietary betaine on growth performance, fat deposition and serum lipids in broilers subjected to chronic heat stress. Anim Sci J. Epub March 17, 2015.

46. Keshavarz K, Fuller HL. The influence of widely fluctuating temperatures on heat production and energetic efficiency of broilers. Poult Sci. 1980;59:2121-2128. 
47. Leung FC, Taylor JE, van Iderstine A. Thyrotropin-releasing hormone stimulates body weight gain and increased thyroid hormones and growth hormone in plasma of cockerels. Endocrinology. 1984;115:736-740.

48. Zulkifli I, Al-Aqil A, Omar AP, Sazili AQ, Rajion MA. Crating and heat stress influence blood parameters and heat shock protein 70 expression in broiler chickens showing short and long tonic immobility reactions. Poult Sci. 2009;88:471-476.

49. Cornell LC, Kang SW, Kuenzel WJ. A possible mechanism contributing to the synergistic action of vasotocin (VT) and corticotropin-releasing hormone $(\mathrm{CPH})$ receptors in corticosterone release in birds: a review. Gen Comp Endocrinol. 2013;188:46-53.

50. Gudev D, Popova-Ralcheva S, Yanchev I, Moneva P, Petkov E, Ignatova $\mathrm{M}$. Effect of betaine on egg performance and some blood constituents in laying hens reared indoor under natural summer temperatures and varying levels of air ammonia. Bulg J Agric Sci. 2011;17:859-866.

51. Messadek J. Modulation of nitric oxide synthesis by betaines. United States patent application 20100305206. May 10, 2007.

52. Monau TR, Vargas VE, Zhang L, Myers DA, Ducsay CA. Nitric oxide inhibits ACTH-induced corticosterone production in near-term, longterm hypoxic ovine fetal adrenocortical cells. Reprod Sci. 2010;17: 955-962.
53. Virtanen E, Rosi L. Effects of betaine on methionine requirement of broilers under various environmental conditions. Poster presented at: Australian Poultry Science Symposium; January 31-February 1, 1995; Sydney, Australia.

54. Amerah AM, Ravindran V. Effect of coccidian challenge and natural betaine supplementation on performance, nutrient utilization, and intestinal lesion scores of broiler chickens fed suboptimal level of dietary methionine. Poult Sci. 2015;94:673-680.

55. Rama Rao SV, Raju MV, Panda AK, Saharia P, Sundar GS. Effect of supplementing betaine on performance, carcass traits and immune responses in broiler chicken fed diets containing different concentrations of methionine. Asian-Australas J Anim Sci. 2011;5:662-669.

56. Rostagno HS, Pack M. Can betaine replace supplemental DL-methionine in broiler diets? J Appl Poult Res. 1996;5:150-154.

57. Schutte JB, De Jong J, Smink W, Pack M. Replacement value of betaine for DL-methionine in male broiler chicks. Poult Sci. 1997;76: $321-325$.
Open Access Animal Physiology

\section{Publish your work in this journal}

Open Access Animal Physiology is an international, peer-reviewed, open access journal publishing original research, reports, reviews and commentaries on all areas of animal physiology. The manuscript management system is completely online and includes a very

\section{Dovepress}

quick and fair peer-review system. Visit http://www.dovepress.com/ testimonials.php to read real quotes from published authors. 